Zuzanna Gawałkiewicz

Uniwersytet im. Adama Mickiewicza

w Poznaniu

zuzanna.gawalkiewicz@gmail.com
Data przesłania tekstu do redakcji: 15.06.2015

Data przyjęcia tekstu do druku: 20.07.2015

\title{
Skazane na melancholię. O emocjach we wspólczesnej chorwackiej poezji kobiecej
}

AвStRact: Gawałkiewicz Zuzanna, Skazane na melancholię. O emocjach we wspótczesnej chorwackiej poezji kobiecej (Destined to Melancholy. Emotions in Contemporary Women's Croatian Poetry). "Poznańskie Studia Slawistyczne" 9. Poznań 2015. Publishing House of the Poznań Society for the Advancement of the Arts and Sciences, pp. 239-253. ISSN 2084-3011.

The aim of the study is to answer the question what the postmodern melancholy is and how it manifests itself through emotions in contemporary works of selected Croatian poets: Božica Zoko, Marijana Radmilović and Tea Gikić. The analysis of poems focused on the theme of body language and metaphors associated with physicality, which are culturally consistent way of expressing melancholy. Postmodern phenomena, such as consumerism, media development, twilight of grand narratives, transformation of the aesthetics of the text, expansion of popular culture or value system instability, which create a melancholic anxiety. Characteristics of postmodern melancholy language have been analyzed which is also the language of women's depression. The theme, most often undertaken by poets, turned out to be the body and language.

KEYWORDS: contemporary Croatian poetry; emotions; melancholia; metaphors; postmodernity

\section{Wprowadzenie}

O pokoleniu debiutującym w latach 90 . XX wieku często mówi się, że zostało owładnięte przez postmodernistyczną obojętność ${ }^{1}$ i nawet tocząca się w Chorwacji wojna nie znalazła szerokiego oddźwięku w poezji młodych, ratno pismo (literatura wojenna) odgrywa w niej marginalną rolę. Analiza twórczości poetyckiej kobiet, które w tym czasie rozpoczęły publikowanie, uprawnia jednak do weryfikacji tezy Krešimira Bagicia z roku 1996. Okazuje się bowiem, że „obojętność na wojnę” nie musi

\footnotetext{
${ }^{1}$ Jest to opinia powtarzana za Krešimirem Bagiciem (1996: 39-40).
} 
oznaczać obojętności na rzeczywistość i rezygnacji z emocjonalności, a nawet, że w poezji tej nietrudno znaleźć motywy wskazujące na traumę wojenną, choć równocześnie obecne są w niej także wątki wskazujące na świadome procesy blokowania emocji. Dobrym materiałem potwierdzającym to rozpoznanie i wielość wpisanych w teksty stanów emocjonalnych jest poezja Tei Gikić, Marijany Radmilović czy Božicy Zoko. Tę wstępną diagnozę, dotyczącą poezji kobiecej, niejako skazanej na emocje przez sam fakt żeńskiego mówienia, potwierdza opinia Sanjina Sorela, obejmująca nie tylko écriture féminine. Wskazuje on, że twórczość tego pokolenia jest w znacznej mierze neoegzystencjalna, skupia się na emocjach i problemie własnej tożsamości, związana jest z figurą pustki (Bagić 1996), przepełniona melancholią i sceptycyzmem (Sorel 2003: 138). Socjologiczno-psychologiczne próby tłumaczenia tej sytuacji wskazują na związek ze skomplikowanym dojrzewaniem pokolenia, które wchodzi w dorosłość, a zaraz potem w przestrzeń literatury, w wyjątkowo depresyjnym momencie historii Chorwacji. Ignorowanie wojennej rzeczywistości nie oznacza jednak zapomnienia. Wyparta ze świadomości wojna, rozpad Jugosławii i formowanie się nowego państwa chorwackiego, powracają w formie palety negatywnych emocji, na czele z lękiem. Obok smutku i poczucia ciężkości, lęk wymieniany jest jako podstawowe doznanie towarzyszące depresji (Kępiński 2001: 90).

Również kobieca poezja wpisuje się w neoegzystencjalny, a jednocześnie melancholijny dyskurs lat 90 . i początku nowego wieku, przesycony nihilizmem, a także poczuciem osamotnienia, niepokoju i zagrożenia związanym z traumatycznymi doświadczeniami. Wśród poetek na wyróżnienie zasługują Zvjezdana Bubnjar, autorka uznawanego za najsmutniejszy i najbardziej depresyjny tomik lat 90. Svjetlocrveno (Zagrzeb 1999)², czy Lana Derkač, której twórczość także przepełniona jest smutkiem. Poezja Tei Gikić, Marijany Radmilović oraz Božicy Zoko wyraża melancholię ponowoczesną i dotyczy nie do końca uświadomionego poczucia straty, związanego m.in. ze współczesnymi zmianami w kulturze i społeczeństwie.

Celem niniejszej pracy jest analiza melancholijnej twórczości wymienionych autorek pod kątem występujących w niej emocji jako klucza

${ }^{2}$ Melancholijna twórczość Zvjezdany Bubnjar jest przedmiotem mojego artykułu Motiv melankolije w tomie Svjetlocrveno Zvjezdane Bubnjar (w druku). 
recepcji rzeczywistości. Ponieważ wśród badaczy nie ma pełnej zgody, kiedy mamy do czynienia $\mathrm{z}$ emocją, a kiedy z uczuciem lub nastrojem, pojęcia te będą używane wymiennie. Smutek najczęściej określa się jako jedną z emocji pierwotnych i uniwersalnych (Turner, Stets 2009: 27). Kępiński w odniesieniu do melancholii posługuje się pojęciem kolorytu emocjonalnego, który w różnych stanach depresyjnych przyjmuje postać ciemności (2001: 94). Interpretacja za pomocą kategorii melancholii uniemożliwia czytanie tekstu w duchu jednej metodologii. Inspirujące w interpretacji melancholijnych wątków okazały się m.in. psychoanaliza, semiotyka i feminizm. Analizowane tomiki Melankolija obilja (1996) Tei Gikić, Bolest je sve uljepšala (2003) Marijany Radmilović oraz Biće iz mraka (2001) Božicy Zoko zostały potraktowane jako jedne z licznych tekstów kultury zrodzonych wokół smutku, tekstów, które nie mogą być zrozumiane przy pominięciu ich kulturowych kontekstów. Emocje wyrażające się w tej poezji związane są z cierpieniem, którego źródło nie jest rozpoznane, z „nic, które boli” (Fernando Pessoa) - zdaniem Bieńczyka, to określenie portugalskiego pisarza jest równocześnie najtrafniejszą definicją melancholii (2012: 17). Melancholia wiąże się z nieokreślonym smutkiem i lękiem. Negatywne uczucia i emocje zniekształcają obraz świata, zabarwiają rzeczywistość (Sartre 2006: 73) i pozwalają spojrzeć na nią w głębszy i dojrzalszy sposób. Z socjologicznego punktu widzenia, funkcją smutku, rozumianego jako wołanie o pomoc, może być także reintegracja jednostki z grupą (Turner, Stets 2001: 31). Negatywne emocje wyrażane w poezji wskazują na tęsknotę za wspólnotą. Z melancholią łączy się również krytyczny stosunek do ponowoczesnych przemian, które wywołują strach, pragnienie powrotu do bezpowrotnie utraconego czasu, izolacji, a nawet śmierci. Należy również dodać, że emocje wyrażane przez podmiot melancholijny niekiedy ulegają zaburzeniu lub nie mogą zostać uzewnętrznione, co w analizowanej poezji wyraża się w metaforach związanych z problemami w komunikacji, milczenia czy też ,zamrożenia” języka.

\section{Emocje i ciało}

Emocje w poezji chorwackich autorek wyrażane są poprzez podkreślanie samotności i wykluczenia jednostki, agresywną krytykę ponowo- 
czesnej kultury i negatywnych zjawisk społecznych, a także język ciała, które jest dla nich najważniejszym systemem komunikacji, pierwotnym sposobem porozumiewania się. Katarzyna Konarska za Desmondem Morrisem przypomina, że mowa ciała jest elementem najsilniej łączącym nasz gatunek, w przeciwieństwie do języków, które, paradoksalnie, z mowy uczyniły system antykomunikacyjny (2011: 9-10). Ta zaskakująca teza jak echo powraca w analizowanej liryce chorwackich poetek. Marijana Radmilović, Tea Gikić i Božica Zoko poruszają w swoich utworach nierozerwalnie złączone ze sobą tematy (utraconego) ciała, języka, komunikacji i tożsamości, które wiążą się z paletą negatywnych emocji.

Stany psychiczne i uczuciowe pojmowane są bardzo często jako byty wewnątrz człowieka, co przejawia się także w stosowanych metaforach (Lakoff, Johnson 1988: 86). Silne emocje mogą wywoływać objawy somatyczne, a metafory są przecież odzwierciedleniem sposobu postrzegania świata. W poezji nie brakuje związanych z cielesnością przenośni, które umiejscawiają emocje, szczególnie te negatywne, we wnętrznościach. Przekonanie o tym, że źródło smutku mieści się w ciele towarzyszy ludzkości od pierwszych refleksji o melancholii. W przeszłości zajmowali się nią nie tylko filozofowie, lecz także medycy, którzy za pomocą różnych kuracji starali się uwolnić czarną żółć z wątroby czy krwi. Stąd częste próby wywoływania wymiotów lub puszczanie krwi melancholikom. Kobiecą melancholię łączono z seksualnością, a narządem odpowiedzialnym za ataki histerii miała być wędrująca macica.

Emocje w utworach Marijany Radmilović wyrażają się w metaforach związanych z cielesnością i fizjologią: „Tuga pliva utrobom” (Razložnost, 2003: 41), a podmiot otrzymuje w darze ,utrobin strah" (Uspavanka II, 2003: 45). W wierszu Ovdje sam se vjenčala (2003: 46) kobieta wyraża pragnienie przeniknięcia do swoich wnętrzności, które rosną i zjadają ją od środka, być może to one są osaczającym ,głodnym mrokiem”. Już Sigmund Freud wspominał o melancholijnym kanibaliźmie (2009: 152), natomiast Marek Bieńczyk przedstawia to zjawisko obrazowo: „W melancholii skrajnej zaprzeczone zostaje nawet ciało: ja, dziecko Saturna, naczynie dla czarnej żółci, nie mam serca, nie mam wątroby, zniknęły moje płuca; noszę w sobie bestię, przechowuję wilka, który pożarł wszystko, co było we mnie" (2012: 24). W tym miejscu warto zwrócić uwagę na jedną z ponowoczesnych tendencji, zmierzających do zaprzestania łączenia 
podmiotowości człowieka z ciałem. Pozornie wyzwalająca propozycja pojmowania tożsamości jako konstruktu ideowego niesie ze sobą zagrożenie w postaci pogardy dla ciała ${ }^{3}$. Wiersze Radmilović w oryginalny sposób tematyzują wszystkie uniwersalne cechy melancholijne, takie jak: depersonalizacja, uwrażliwienie na kruchość i niewyrazistość granic indywidualnej tożsamości, a także skłonność do powtórzenia (Bieńczyk 2012: 59).

Warto zwrócić uwagę, że ciało w poezji Marijany Radmilović jest naznaczone chorobą. Choroba nie jest jednak waloryzowana negatywnie, ból okazuje się bowiem głosem ciała: „čujem šapat bolešjiva koljena. / Tijelo je uvijek dobra riječ" (Potreba, 2003: 7). Cierpienie fizyczne i psychiczne to zarówno przekleństwo, jak i błogosławieństwo, ponieważ bywa destrukcyjne, ale prowadzi też do samopoznania. Choć ból często obezwładnia zmysły, w przypadku podmiotu melancholijnego paradoksalnie przynosi ukojenie. Świat wydaje się dla melancholika ruiną, chaosem zbyt szybkich przemian (,Paryż się zmienia! Lecz trwa w smutku mego glorii!” [Baudelaire 1970: 91]), dlatego ból stanowi jedyny punkt odniesienia. Teza ta znajduje swoje odzwierciedlenie w interpretowanej poezji, w której ciało to jedyna niedającą się unicestwić realność. Radmilović stara się wyrazić niewyrażalne, przedstawić ciało w jego wielowymiarowości. Jego obraz wyłaniający się z tej twórczości okazuje się bliski definicji Elizabeth Grosz, czołowej badaczki feminizmu korporalnego. Według niej ciało jest:

konkretną, materialną, ożywioną organizacją tkanki mięsnej, organów, nerwów i struktury kostnej, która uzyskuje pełnię, spójność i formę dzięki psychicznej i społecznej inskrypcji powierzchni ciała, (które jest - Z.G.) organicznie, biologicznie ,niekompletne"; jest niezdeterminowanym, amorficznym zbiorem nieuporządkowanych możliwości, które wymagają społecznego treningu, uporządkowania, długoterminowego „administrowania”. Ciało staje się ludzkim ciałem, ciałem, które współwystępuje i pokrywa się z przestrzenną formą duszy, ciałem, które określa granice własnego doświadczenia i podmiotowości, tylko poprzez ingerencję matki oraz, ostatecznie również, Innego (reprezentującego język - i reguły rządzące społecznym porządkiem) (Świerkosz 2008: 79-80).

Również w twórczości Radmilović ciało to jednocześnie fizyczna, materialna tkanka i obszar inskrypcji Innego. Przynależy zarówno do przestrzeni fizycznej, jak i psychicznej, duchowej, społecznej. Jest przede

${ }^{3}$ Vide Oraić-Tolić 2001. Badaczka podaje przykład powieści Slavenki Drakulić Božanska glad (1995), która porusza temat kanibalizmu. 
wszystkim możliwością. I właśnie taki dynamiczny, nie do końca uchwytny obraz ciała odkrywa poezja chorwackiej autorki.

Wiersz Tei Gikić Tako pjeva Dunja, inspirowany śpiewem Dunji Vejzović (Barbieri 2009), śpiewaczki operowej, znanej na całym świecie z pięknego sopranu, ukazuje ból jako centrum kobiecego ciała:

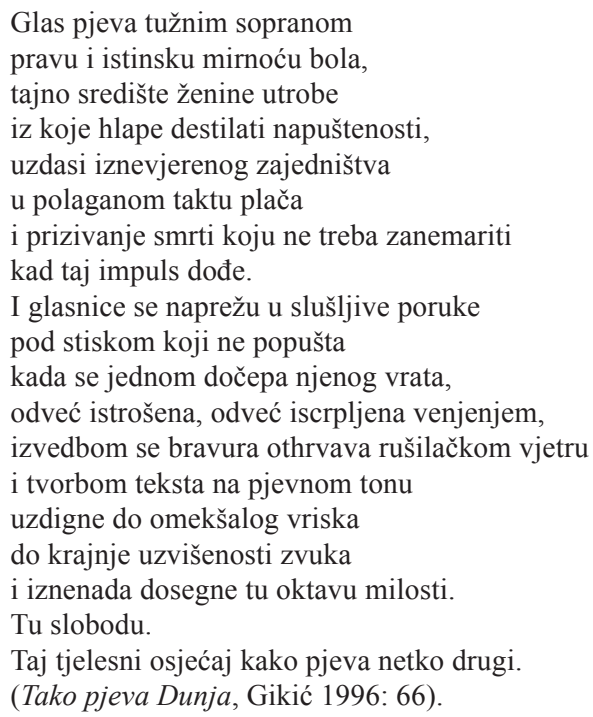

W utworze, którego tematem jest śpiew, dochodzi do przenikania się dwóch kodów - poetyckiego i muzycznego (Tomić 2009). Słowa sopran, westchnienie, takt czy impuls przynależą do słownictwa muzycznego. W wierszu zostały one skonfrontowane z motywem bólu, który jest centrum kobiecego wnętrza. Poczucie opuszczenia wskazuje na stan długotrwałego cierpienia, którego ostatnim etapem jest pragnienie śmierci. Symboliczna „zdradzona wspólnota” może oznaczać zarówno odrzucenie ze strony grupy osób, jak i niewierność mężczyzny, a także zerwanie najbardziej intymnej jedności z nienarodzonym dzieckiem, o czym mógłby świadczyć fragment sugerujący przerwanie ciąży „tajno središte ženine utrobe / iz koje hlape destilati napuštenosti". Podmiot liryczny został „rozczłonkowany” na głos, struny głosowe i brawurę. Zarówno śpiew, rodzący się w bólu w kobiecym, opustoszałym łonie (symboliczny poród), 
jak i jego słuchanie, są doświadczeniem cielesnym. Śpiew przyrównany został do płaczu. Ostatni wers sugeruje, że słuchaczem staje się sama wykonawczyni pieśni - ból wraz z głosem odrywa się od podmiotu, czy też podmiot za pomocą ekspresji głosu uwalnia się od udręki. Smutek tej pieśni nie jest tylko chwilową kreacją nastroju, lecz „rodzi się” z realnego cierpienia, które ma wymiar cielesny i duchowy. „Omekšali vrisak” jest więc krzykiem prawdziwego, kobiecego bólu, ubranym w łagodzącą go, artystyczną formę.

\section{Emocjonalna pustka}

Melancholijny podmiot niekiedy w lęku przed zbliżeniem się do drugiego człowieka zamyka się na interakcję, żyje w emocjonalnej pustce. Kobiecość jest ukazana w poezji Tei Gikić jako wieczne niespełnienie, a relacje międzyludzkie jako kontakt pozbawiony uczuciowego zaangażowania. Wiersz Ljubavni uzmak w oryginalny sposób wyraża akt erotyczny. Pełna dystansu analiza rozczarowującej, niedoskonałej miłości może być wyrazem tęsknoty za uczuciem, które byłoby wzniesieniem ponad cielesność, przeżyciem niemal metafizycznym, choć destrukcyjnym. Zamiast tego ciało doświadcza namiastki namiętności, która przynosi pocieszenie:

\footnotetext{
Nakon poljupca iz kojeg se ne klone u zaborav svako je darivanje tijela djelomično.

Izvedeno iz naše uobičajene osjetljivosti, bez lakomosti i pukog rasipanja uhvaćeno u projekciju volje u potaji pohranjeno među skorene požude, kao sretan znak uračunatog pripadanja, unutarnje pokriće privremenih zaluđenosti čija se nedokučiva istovjetnost potreba nudi kao pokušaj iskupljenja i pogrešno shvaćena uzbuđenost i čulna se napetost teških kapaka baca pod nas kao namotane bale u trajnoj nedoumici prevara i olakšanja kojima je lako podleći.
} 
Tu strast ništa ne opravdava.

Pritještena tjeskobom svoga trajanja

Samo je neoprostivo utješna.

(Ljubavni uzmak, Gikić 1996: 27).

Gikić opisuje akt miłosny jako efekt racjonalnego postępowania, akt woli pozbawiony emocji i uczuciowego zaangażowania, który został przeciwstawiony niekontrolowanemu, zachłannemu przypływowi namiętności. Istotnym tropem interpretacyjnym dla całego utworu jest pierwszy wers, który uzmysławia, że mamy do czynienia z czasem „po” pocałunku, który wszystko odmienił, scementował na zawsze, nie pozwolił zapomnieć. Po tym akcie wszystkie inne próby spełnienia są jedynie namiastką, spełnieniem cząstkowym, potwierdzaniem przynależności.

Przyimek „po” to bodaj najkrótszy komunikat obwieszczający stan melancholii. Oto, niezależnie od obiektywnych wymiarów czasu, żyjemy w przestrzeni „po”: dzieciństwie, szczęściu, miłości, życiu bliskich, własnym życiu. Obserwujemy siebie jako kogoś obcego (Świeściak 2010: 204).

Tea Gikić poświęca kobietom wyjątkowe miejsce w swoim tomiku Melankolija obilja. Dzieli się on na dwie części: Esej o ženama i Esej $o$ otuđenosti. Pierwsza z nich zawiera poetyckie, melancholijne portrety kobiet. W utworze Dugo same žene zarysowuje obraz kobiecej samotności, pełnej lęku i uczucia niespełnienia. Emocje towarzyszące rozstaniu przeobraziły się w stan długotrwałego, wyniszczającego smutku:

Dugo same žene pune su tjeskobe

Njihove neprimjerene zaljubljenosti

u stalnom kašnjenju za nehajnim spokojem

kao trave poredane prema pukoj bezazlenosti,

ostavljaju dovoljan razlog slutnjama

i žalovanju čiji se suvišno oplakan objekt

praktično nosi umjesto uzdaha

i drži srce na željenoj visini

i ostaju odane žudnjama svoje volje

u tajnom savezu s naklonjenim prosudbama

kao nekim znakom zrelosti

u čiji učinak imaju uvid

i čiji je jedini sadržaj melankolija 
iz sasušenog poljskog cvijeća,

konstrukcija vođenja ljubavi bez vonja, poznata arija u drugom tonalitetu od koje se širi nejednolika sjena po tvrdom rubu šarenice.

Za njih je prekasno, a ne prerano.

(Dugo same žene, Gikić 1996: 11).

Doświadczone stratą kobiety w cytowanym wierszu „noszą” ze sobą swój obiekt żałoby, jednak nie chodzi o dosłowne noszenie choćby symbolicznego znaku straty, lecz o przełożenie stanu emocjonalnego na fizyczne funkcjonowanie. Opłakiwany obiekt zastępuje bowiem oddech. W obrazie Gikić cierpienie przyjęło postać melancholii, zostało oswojone i stało się częścią podmiotu, zagnieździło się w ciele kobiety. Poetka werbalizuje jednak przekonanie, że melancholia zakrzywia obraz rzeczywistości, jak cień, który przysłania tęczówkę oka. Ma też swój wymiar nostalgiczny, niemal kiczowaty, symbolizowany przez zasuszone polne kwiaty. Wiersz jest też krytyką kobiet, które kochają zawsze w niewłaściwy sposób, ich miłość jest nieadekwatna lub spóźniona. Kobieta sportretowana w wierszu chorwackiej autorki, oddana wyłącznie swoim pragnieniom i ufająca nieobiektywnym ocenom, nie zazna prawdziwego uczucia, lecz jedynie jego marną kopię, co oddaje metafora kwiatów bez zapachu.

W wierszach Božicy Zoko również nie brakuje cielesnych metafor dla określenia melancholijnych stanów. Podobnie jak w twórczości Tei Gikić pojawia się motyw zbliżającej się apokalipsy, choroby, infekcji, która opanowuje język. Dochodzi do „zamrażania” emocji, które uniemożliwia wyrażanie siebie i kontakt z drugim człowiekiem. Oto fragmenty wiersza Užitak:

Sve će se uskoro raspasti. Valja se privikavati na mrak koji će ostati iza nas.

***

Rasap i razgradnja.

Predviđam evoluciju govora sve do retoričkih pitanja, jezik

pregrizla. Odgovor je u ledu, jer led zaustavlja.

Ali - dolaze vrućine. Infekcija. I još neće biti kraj.

(...)

Mir. Tišina. Sraz.

Ne znam. Ne znam. Ne znam.

Možda, možda, možda. To je sve što znam reći, a mogu. 
Mogu zamisliti svaki prijedlog, predpostavku, perspektivu, plan;

Uvidjeti dokaz ikakav - ali ma kakav rezultat bio - svih

istraživanja, dostignuća, otkrića - nikad ništa

neće dospjeti do mog sebeužića. To put je beskonačan.

Apokalipsa.

(Užitak, Zoko 2001: 18-19).

Apokalipsa to nie tylko koniec świata, lecz również degradacja języka, a rozpad języka jest jednocześnie rozpadem podmiotu. W pesymistycznej wizji Božicy Zoko (która jest podobna do wizji Radmilović ${ }^{4}$ ), język już nie służy komunikacji. W świecie, który stoi nad przepaścią, trudno też szukać przyjemności. Poetka kreśli obraz świata będącego terenem nieustannej produkcji i nowych odkryć, które jednak nie pomagają w najważniejszym życiowym celu - dotarciu do samego siebie, a nawet ograniczają wolność jednostki. Również wewnęrzny świat człowieka nie jest już chroniony, ponieważ o jego sekretnych myślach, a nawet o nieświadomości, rozprawia się w mediach. Wszystkie te zabiegi poetka nazywa „kampanią ograniczania" (Užitak, Zoko 2001: 19).

W melancholii odczuwanie pozytywnych emocji jest ograniczone. Zoko idzie o krok dalej i dekonstruuje samo pojęcie przyjemności. Czy można bowiem poszukiwać jej w ponowoczesnym świecie, skoro podmiot wyznaje: ,ne vjerujem u postojanje užitka kao zasebnog, odvojenog i prepoznatljivog stanja koje ima početak, sredinu i kraj” (Užitak, Zoko 2001: 18)? Cytowana definicja przyjemności, która określa ją jako uchwytne zjawisko, poddające się badaniu i klasyfikacji, budzi sprzeciw podmiotu. Przyjemność może jednak kryć się pomiędzy słowami, wpisana jest bowiem w samo melancholijne wyznanie. „Bolesna słodycz rozpamiętywania" (Zaleski 2004: 13) jest swoistym pocieszeniem. Sanjin Sorel zwraca również uwagę na kobiecą melancholię, którą definiuje słowami Renaty Salecl: ,jouissiance što ga žena nalazi u melankoličnoj izdvojenosti iz svijeta upravo i jest oblik ženskog užitka" (Sorel 2006: 141).

Słowem-kluczem w poezji Zoko, oznaczającym „uwięzienie” podmiotu w negatywnych emocjach, które zniekształcają obraz świata, jest ciemność. Zvonimir Mrkonjić stwierdza, że lektura jej wierszy to zanurzenie

${ }^{4}$ Motyw martwych, pozbawionych wnętrza słów oraz milczenia pojawia się bardzo często w poezji chorwackiej poetki, cf. K. Pieniążek-Marković 2011: 312-316. 
się w czerni, stąd też wymowny tytuł recenzji omawianego tomiku $\mathrm{Su}$ očenje s mrakom (Mrkonjić 2006: 384-385). Czerń, która rodzi się z melancholii, pochłania całą rzeczywistość. Ciemność jest nie tylko poetycką metaforą, używa jej również Antoni Kępiński, opisując sytuację cierpiącego na depresję. To w niej gromadzą się wszystkie lęki chorego, jest esencją zrujnowanej psychiki:

(We śnie - Z.G.) stopień odejścia od rzeczywistości jest proporcjonalny do nasilenia ciemności. W mroku kontury przedmiotów się zmieniają, przeważnie ulegają wyolbrzymieniu; w całkowitej ciemności tworzą się już całkiem nowe formy, często nic z rzeczywistością nie mające wspólnego (...). Analogiczne zjawisko można obserwować w depresji; w lżejszych depresjach drobne kłopoty ulegają patologicznemu wyolbrzymieniu, w głębokich tworzą się już chorobliwe konstrukcje, nie mające często nic wspólnego ze stanem rzeczywistym (...). W depresjach psychotycznych chory rzutuje w ciemną przestrzeń swe tajone lęki, agresje, poczucia winy itd. Przestrzeń ta zapełnia się psychotycznymi tworami (Kępiński 2001: 95).

\section{Kolektywne emocje i nastroje}

Melancholia i związane z nią negatywne emocje są często przyrównywane do choroby. Co ciekawe, nie ma ona charakteru wyłącznie jednostkowego, lecz może określać zbiorowość. Negatywne emocje, takie jak strach i frustracja, są efektem nieprzepracowanej traumy. Wierność wobec obiektu straty uniemożliwia odczuwanie pozytywnych emocji, a wszelkie przejawy beztroski i radości traktowane są w kategoriach zdrady. W poezji Tei Gikić melancholia to zjawisko tak powszechne jak reumatyzm (, širi se reumatizam i melankolija", Travanjski vjetar što zamire, 1996: 33). Poetka stawia tezę, że za szerzenie się chorób i niepokoju odpowiedzialny jest tajeminiczy wiatr ${ }^{5}$ sprawiający, że tracimy na wadze (Most, 1996: 38). Kwietniowy wiatr zabija nie tylko tulipany, lecz także wiedzie do samobójstwa. Choć Gikić szczególną uwagę poświęca kobietom, cierpienie w jej wierszach nie ma wyłącznie wymiaru kobiecego ani też jednostkowego. Zgodnie z tytułem wiersza Šira interpretacija straha (1996: 63), autorka dokonuje „,szerszej interpretacji strachu”, na który składają się kolektywne frustracje

${ }^{5} \mathrm{O}$ zależności między wiatrem (np. występującym na wschodnim wybrzeżu Morza Adriatyckiego jugo) a melancholią pisze wyczerpująco Leszek Małczak, vide Małczak 2004. 
i zbiorowa trauma. Poetka zwraca uwagę na emocje, które towarzyszą ludziom doświadczonym traumą wojny oraz zagubionym w ponowoczesnym świecie. Wspólne „fundusze napięć”, potęgowane kolektywnymi frustracjami, snobizm zapominania czy lekceważenie traumy blokują myślenie społeczeństwa i uniemożliwiają rozwój. Gikić zarzuca mu bierność i pogardę wobec traumy, której znakiem są rozklejane nekrologi. Być może w ten sposób sygnalizuje potrzebę mówienia o obojętności społeczeństwa wobec tych, którzy zginęli na froncie, oraz wobec ich rodzin lub o braku zainteresowania ofiarami, które przeżyły wojnę, lecz mierzą się z rozmaitymi problemami (utratą bliskiej osoby, kalectwem, zespołem stresu pourazowego itp.). Skłonność do zbyt łatwego zapominania przejawia się beztroską symbolizowaną przez różowe szpaki. W poezji chorwackiej autorki pamięć jest wartością, a wspomnienia należy chronić.

Znakiem ponadjednostkowej melancholii może być przemawianie w imieniu zbiorowości, tak jak ma to miejsce w wierszu $U$ žalosti. Jest on ilustracją niekończącej się żałoby po nieodwracalnej, nieodżałowanej stracie. Utwór jest diagnozą społecznych nastrojów - lęku, smutku i rezygnacji.

\section{Gubitak je nepovratan}

Hladni i prazni raporti u nemoći

Nedramatične lokacije i prešutne manjkavosti

što propagandnim šiframa obmana

šire isti zadah tjeskobe,

pokazat će se pukim održavanjem

na bučnoj topografiji izazova

na golim pločicama intime

čija nemilosrdnost ide jako daleko

u napredovanju katastrofe po mjeri duha

u natruhama pretpostavljene sudbine

što lebdi kao suzava malodušnost

i akcija poništena u vremenu

i riskirajući potpunu osamljenost

kao upijači kojima su mane urođene

i organizirani volumeni tuge

koji se ne smiju pokazati javno,

ozdravljamo kroz žalosti,

poučno zabodene u gubitkom razorena mjesta.

(Užalosti, Gikić 1996: 20). 
Również w tym utworze można odnaleźć cielesne metafory, a nawet synestezje: „šire isti zadah tjeskobe, / pokazat će se pukim održavanjem / na bučnoj topografiji izazova / na golim pločicama intime". Wiersz obfituje w wyrażenia, które dokonują transpozycji wrażeń:

Transpozycja wrażeń, będąc fenomenem percepcji i zarazem konstruktem językowym, ma swoje miejsce w instrumentarium poetyki (gdzie jest metaforą, metonimią lub personifikacją). Należy także do zjawisk z zakresu estetyki recepcji. Synestezja bowiem, będąc szczególnym przypadkiem metafory, także „nie ma granic” (Legeżyńska 2004: 138).

Użycie środków stylistycznych, które wyrażają złą kondycję psychiczną podmiotu, pomieszanie zmysłów, ma na celu oddanie stanu chaosu, w którym znajduje się osoba przeżywająca stratę: „hladni i prazni raporti u nemoći” „zadah tjeskobe”, „bučna topografija izazova”, „gole pločice intime”, ,suzava malodušnost”, „organizirani volumeni tuge”. Melancholia odłącza się od podmiotu i zaczyna określać rzeczywistość. W wierszu dominuje metaforyka wojenna, która opisuje konflikt wewnętrzny, wyrażająca się poprzez słownictwo typu: raport, lokalizacja, akcja, ryzyko, katastrofa, szyfr propagandy, „rozorane miejsce” - miejsce po wybuchu, rana. Nagromadzenie leksyki i metaforyki z rejestru właściwego dla walki czy konfliktu może wskazywać na obecność wojennej traumy, na niedokończony proces żałoby, który nie może dokonać się z powodu otwartej rany jaką jest nieodwracalna strata.

\section{Podsumowanie}

Chorwackie poetki w odmienny sposób podejmują tematy kobiecości, ciała, języka i tożsamości, jednak łączy je koncentrowanie się na negatywnych uczuciach i emocjach, związanych z przepracowywaną stratą. Emocje te wyrażają się poprzez ciało, najważniejszy system komunikacji. Kobiece ciało jest jednym z głównych tematów tej poezji, a Radmilović, Gikić i Zoko poruszają problem kobiecości jako części własnej tożsamości. Próbują dekonstruować stereotypową koncepcję kobiecości, ale też zdają sobie sprawę z mnogości jej kulturowych projekcji. Obraz ciała, który wyłania się z interpretowanych utworów wskazuje na niechęć 
do ukazywania go jako przedmiotu. Ciało jest domem emocji, tekstem, fundamentem tożsamości, niedoskonałym sposobem komunikowania się w świecie, w którym język nie służy przekazowi i nie może być narzędziem wyrażania kobiecej straty. Ponowoczesne przekonanie o bezsilności języka jako środka wyrazu i komunikacji międzyludzkiej przepełnia poezję chorwackich autorek. Głosem ciała może być ból zarówno fizyczny, jak i psychiczny. W poezji Tei Gikić, Marijany Radmilović i Božicy Zoko odczytać można jednocześnie zmysłowość, cielesność i emocjonalność. Należy podkreślić, że przeważają w niej negatywne emocje, związane z traumą wojny, doznaną stratą, samotnością i problemami w komunikacji. W skrajnych przypadkach dochodzi do ich zaprzeczenia, do niemożności wyrażenia siebie i nawiązania kontaktu z drugim człowiekiem. Interpretacja w kluczu melancholii pozwala spojrzeć inaczej na postmodernizm, niesłusznie kojarzony wyłącznie z kategorią gry, z zabawą, powierzchownością i wolnością. Z pewnością jest to poezja daleka od postmodernistycznej obojętności, przepełniona melancholią oraz jednostkowym i kolektywnym cierpieniem.

\section{Literatura}

Bagić K., 1996, Praznina u suvremenom hrvatskom pjesništvu, „Kolo” nr 1, s. 5-44. Barbieri M., 2009, Ruža za kavalira. Hrvatski umjetnici u Bečkoj državnoj operi (od 1945. do danas), ,Vijenac” nr 347, <http://www.matica.hr/vijenac/349/Ru$\% \mathrm{C} 5 \% \mathrm{BEa} \% 20 \mathrm{za} \% 20 \mathrm{kavalira} />, 1.05 .2015$.

Baudelaire Ch., 1970, Łabędź, w: idem, Kwiaty zła, wyb., oprac. i wstęp M. Jastrun, przeł. A. Lange i in., Warszawa.

Bieńczyk M., 2012, Melancholia: o tych, co nigdy nie odnajda straty, Warszawa.

Bubnjar Z., 1999, Svjetlocrveno, Zagreb.

Freud S., 2009, Psychologia nieświadomości, przeł. R. Reszke, Warszawa.

Gikić T., 1996, Melankolija obilja, Zagreb.

Grosz E., 1994, Volatile Bodies. Toward a Corporeal Feminism, Bloomington.

Kępiński A., 2001, Melancholia, Warszawa.

Konarska K., 2011, Niesforne ciało, w: Ciało cielesne, red. eadem, Wrocław, s. 9-18.

Lakoff G., Johnson M., 1988, Metafory w naszym życiu, przeł. i wstęp T.P. Krzeszowski, Warszawa.

Legeżyńska A., 2004, Pteć synestezji, w: Literatura i język, red. K. Meller, K. Trybuś, Poznań, s. 133-143.

Małczak L., 2004, Wiatr w literaturze chorwackiej. O figurze literackiej wiatru w XIXi XX-wiecznym piśmiennictwie chorwackim strefy śródziemnomorskiej, Poznań. 
Mrkonjić Z., 2006, Suočenje s mrakom, w: idem, Perivoji pjesništva II., Zagreb.

Oraić-Tolić D., 2001, Muška moderna i ženska postmoderna, „Kolo” nr 2, s. 220-232.

Pieniążek-Marković K., 2011, „Ja”-człowiek $i$ świat w najnowszej poezji chorwackiej (1990-2010), Poznań.

Ramilović M., 2003, Bolest je sve uljepšala, Zagreb-Požega.

Sartre J.P., 2006, Szkic o teorii emocji, przeł. R. Abramciów, Kraków.

Sorel S., 2003, Pjesništvo devedesetih, w: Postmodernizam, iskustva jezika u hrvatskoj književnosti i umjetnosti, ur. C. Milanja, Zagreb, s. 131-146.

Sorel S., 2006, Neoegzistencijalistički diskurz devedesetih, w: idem, Isto i različito: antologija i studia hrvatskog pjesničkog naraštaja devedesetih, Zagreb.

Świeściak A., 2010, Melancholia w poezji polskiej po 1989 roku, Kraków.

Świerkosz M., 2008, Feminizm korporalny w badaniach literackich. Próba wyjścia poza metaforykę cielesności, „Teksty Drugie” nr 12, s. 75-95.

Turner J.H., Stets J.E., 2009, Socjologia emocji, przeł. M. Bucholc, Warszawa.

Tomić M., 2009, Stilistička analiza pjesme Tee Gikić „, Tako pjeva Dunja”, „Hrvatistika" nr 3, s. 117-126.

Zaleski M., 2004, Formy pamięci, Gdańsk.

Zoko B., 2001, Biće iz mraka, Zagreb. 